\section{Bivalve-growth Patterning as a Method for Seasonal Dating in Archaeology}

A whaEological evidence is often found for the expioitation of marine resources. In New Zealand, one of the rnost widespread spccies exploited was the intertidal bivalve Chione stutchburyi, and its growth dynamics form the basis of the technique described here, the purpose of which is to determine at what time of the year shells were collected.

Following the approach of other workers, studies of living populations of Chione indicated that, in general, the bands or rings on the surface of the shells (macrorings) were the result of winter growth recession ${ }^{1-4}$. Further, when cross-sections of the shells were photomicrographed (Fig. 1) two major types of banding (microrings or bands) were observed - fine black bands and relatively broad white bands. The latter sometimes contain faint dark lines, indicating two growth phases betwen each black band. In a sample of twelvo modern shells the number of major black rings between the two major winter rings varied from 300 to 420 with a mcan of 358 , suggesting that the black bands may bo formed daily.

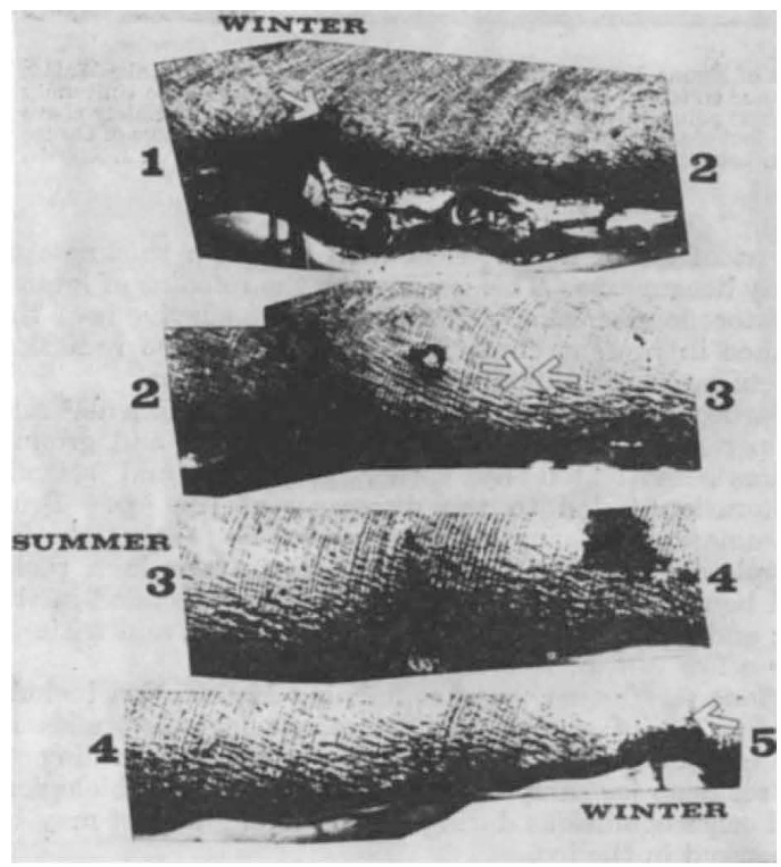

Fig. 1. Photomicrograph of a transverse section through the umbo of Chione stutekhnryi. Daily micro bands arc clourly discernible between the antual growth rings (makro bands). The latier are indicated in the of a paic of bidaily bands.

There is also considerable variation in the width of the bands throughout the year; they are very much wider in summer and spring.

An approximate estimate of the season of death of both modern and archaoological sholl samples may be made, first by examining the variation in the thickness of the daily bands from the last macro-ring to the shell margin, and then by counting the number of daily growth bands from the last macro-ring to the shell margin. Provided that the approximate date when the macrorings are formed is known, tho dato of death of individual shollfish may be estimated. For Chione this was detormined by observing the growth dynamics of living populations over a period of twelvo months.

A comparison between the known and estimated dates of death in twelve modern specimens (Table 1) suggestod.
Table 1. COMPARISON OF ESTIMATED DATES OF DEATH OF Chione stutchburyi WI'H KNOWN DATHS OF DEATH FROM THREE COILEC'IING AREAS Date of Sample black bands from based on variations Locality collection No, last winter rings in the width of the Arca B

Doctors Point $20 / 4 / 69 \quad 4 \quad 234 \pm 20 \quad$ Autumn

Area B
Doctors Point $23 / 5 / 69 \quad 4 \quad 275 \pm 20 \quad$ Autumn

$\begin{array}{lrrrr}\text { Tiwai Point } & 9 / 4 / 69 & 4 & 275 \pm 20 & \text { Autumn } \\ \text { Tiw } & & 220 \pm 15 & \text { Autumn }\end{array}$

that an accuracy within a range of three months can be obtained.

The mothod has been applied to shells from severa! coastal sites in New Zealand and the estimated scasonal dates, along with those obtained from other faunal data, are shown in Table 2.

Table 2. HSTIMATEI) DATES OF DEATH OF SHELLS FROM TIRRE ARCILAEOLOGICAL STTES IN SOUTIERN NEW ZHALAND COMPARED WITH SHASONAL DATES DEDUCED THALAND COMTARED WIT

\begin{tabular}{|c|c|c|c|c|c|}
\hline $\begin{array}{l}\text { Location of } \\
\text { archaeological sites } \\
\text { and stratigraphic } \\
\text { position }\end{array}$ & $\begin{array}{r}\text { Sh } \\
\text { spe } \\
\text { consi }\end{array}$ & $\begin{array}{l}\text { cll } \\
\text { cies } \\
\text { dered }\end{array}$ & $\begin{array}{l}\text { Average } \\
\text { No. of } \\
\text { black bands } \\
\text { from last } \\
\text { winter } \\
\text { ring } \\
\text { to shell } \\
\text { margin }\end{array}$ & $\begin{array}{l}\text { Estimated } \\
\text { months } \\
\text { during } \\
\text { which shells } \\
\text { were col- } \\
\text { lected (by } \\
\text { microscopic } \\
\text { technique) }\end{array}$ & $\begin{array}{l}\text { Estimated } \\
\text { period of } \\
\text { year when } \\
\text { site was } \\
\text { occupied } \\
\text { from other } \\
\text { faunal } \\
\text { evidence }\end{array}$ \\
\hline Tiwai Pcint TW PQ/40 & $\begin{array}{l}\text { Chione } \\
\text { stutc }\end{array}$ & buryi & $110 \pm 10$ & Dec-Feb & Oet-April \\
\hline Tiwai Point P/30 & ," & , & $90 \pm 10$ & Xov-Jan & Oct-April \\
\hline $\begin{array}{l}\text { ST/1 TR B, sq 3, spit } 1 . \\
\text { Concentrated mid- } \\
\text { den (SP = Southport) }\end{array}$ & " & ", & $146 \pm 15$ & Dec-Mar & Nov-June \\
\hline $\begin{array}{l}\mathrm{SP} / 1 \text { TR } \mathrm{C}, \mathrm{sq} 1 . \\
\text { Concentrated inidden }\end{array}$ & ," & ", & $120 \pm 15$ & Dec-Feb & Nov-June \\
\hline $\begin{array}{l}\text { SP/4 TR C and D, } \\
\text { sq } 2 \text { and } 3 . \\
\text { Cockle }\end{array}$ & ," & ," & $128 \pm 25$ & Nov-Mar & Nov-June \\
\hline $\begin{array}{l}\text { SP/5 TR H, } \mathrm{sq}-5 \text {. } \\
\text { Spit } 2 \text {. Organic }\end{array}$ & ", & $"$, & $101 \pm 20$ & Dec-Feb & Nov-June \\
\hline $\begin{array}{l}\mathrm{SP} / 5 \mathrm{TR} \\
\text { Spit } 2\end{array}$ & & ", & $103 \pm 10$ & Dee Feb & Nov-June \\
\hline Wakapatu & $\begin{array}{l}\text { Prototh } \\
\text { crassi }\end{array}$ & & $200 \pm 20$ & Mar-April & Oct-April \\
\hline
\end{tabular}

Thus in New Zealand, at sites such as Tiwai Point and Wakapatu, the relatively thin midden doposits and presence of the bones of migratory birds suggest temporary occupation during tho summer. In advancing a hypothesis that the sites were occupied at this time of the ycar for the exploitation of seasonal food sources, it must nevertheless be romembered that both fish and birds wore dried and transported over fairly great distances during the protohistoric period in southern New Zcaland. A means of checking this hypothesis is necessary. Although shells were also carried quite far during the protohistoric period in New Zealand, the number and weight of the shells that constitute the coastal middens in question rule out the possibility that they were transported to the sites from clscwhere. Shellfish wero dried and stored during the protohistoric period ${ }^{5}$, though there is no evidence that large quantities of the shells themselves were carried over any distance from the point of collection.

The implications of these results for the prehistorian are clear. The technique described provides not only a check but also a fairly refined estimate of the season at which the sites were occupied.

\section{P. J. F. Coutts}

Department of Anthropology,

Otago University,

Dunedin,

New Zealand.

Received December 22, 1969; revised February 17, 1970.

1 Panella, G., MacClintock, C., and Thompson, M. N., Science, 162, 792 (1968).

2 Berry, W. 13. N., and Barker, R. M., Nature, 217, 938 (1068),

${ }^{8}$ House, M. R., and Farrow, G. E., Nature, 219, 1384 (1968).

${ }^{4}$ Clark, G. R., Science, 161, 800 (1968).

${ }^{3}$ Leach, B. F., Monograph Series, Anthropology Dept, University of Ota7o, 1 (1968). 